\title{
Rasio Keuangan, Financial Distress Dalam Prediksi Kebangkrutan Perusahaan Manufaktur
}

Firda Rismadhani ${ }^{1}$, Ana Kadarningsih ${ }^{2}$

${ }^{1}$ Universitas Dian Nuswantoro, email : 211201604213@mhs.dinus.ac.id

${ }^{2}$ Universitas Dian Nuswantoro, email : ana.kadarningsih@dsn.dinus.ac.id (correspondence author)

\begin{abstract}
ARTICLE INFO
Article history:

Received 30 Mei 2020

Received in revised form 2Juni2020

Accepted 10Juni2020

Available online 12Juni2020

\section{ABSTRACT}

Financial distress is a financial condition of a company that is in a state of crisis. The purpose of this study is to find out the effect of liquidity, leverage, operating capacity, profitability, and firm growth on financial distress. The population of this study is manufacturing companies listed on the Indonesia Stock Exchange in 2017-2018 with the sampling technique using porposive sampling or criteria. Based on the technique, obtained sample of 112 companies. The results of this study indicate that liquidity and profitability has a significant effect on the financial distress of manufacturing companies listed on the Indonesian stock exchange. Meanwhile, leverage, operating capacity, and firm growth have no effect on the financial distress of manufacturing companies listed on the Indonesian Stock Exchange.
\end{abstract}

Keywords: financial distress, profitability, liquidity

\section{Introduction}

Financial Distress merupakan langkah dimana keadaan finansial yang timbul sebelum mengalami terpurukan. Jika kondisi tidak cepat dituntaskan perusahaan tersebut bisa berakibat besar seperti lunturnya kepercayaan dari kelompok, dan justru perusahaan tersebut dapat mengalami kebangkrutan. Ada dua penyebab yang memicu kebangkrutan yaitu faktor dalam dan faktor luar. faktor internal dapat dilihat dari segi finansialnya, seperti hutang perusahaan tidak dapat membiayai kegiatan operasionalnya [23].

Fenomena yang terjadi di Indonesia yaitu terjadinya delisting perusahaan pada tahun 2018. Delisting yaitu apabila saham yang tercatat di Bursa mendapati depresiasi standar sehingga tidak melengkapi kualifikasi pendataan, maka saham tersebut bisa dikeluarkan dalam pencatatan yang terdapat di Bursa. Pada kasus DAJK, Bursa Efek melakukan proses delisting karena perusahaan mengalami kepailitan setelah gagal membayar hutang. DAJK listing pada 14 Mei 2018 dan resmi dikeluarkan pada 18 Mei 2018. TRUB delisting pada 12 September 2018 dikeluarkan dikarenakan perusahaan mengalami going concern dan perusahaan tidak dapat melakukan perbaikan dari sisi operasional. JPRS delisting pada 8 Oktober 2018 karena akan koalisi dengan PT Gunawan Dianjaya Steel Tbk (GDST). Pada kasus SQBB delisting pada 21 Maret 2018 Bursa Efek melakukan delisting paksa karena perusahaan tidak mampu memenuhi persyaratan BEI. 
Kinerja keuangan suatu perusahaan yang tidak stabil dapat mengakibatkan delisting. Pengukuran kinerja keuangan perusahaan dapat menggunakan berbagai rasio, salah satunya yaitu ROA (Return On Asset). Pengukuran menggunakan ROA bertujuan untuk menunjukan bahwa keseluruhan dari kepemilikan aktiva yang digunakan oleh perusahaan untuk mengoperasikan perusahaan dapat memberikan atau menghambat laba yang akan berpengaruh terhadap pertumbuhan perusahaan. Berikut adalah disajikan grafik rata rata ROA perusahaan manufaktur selama 2 tahun yaitu 2017 - 2018 yang menunjukan adanya perubahan pada Figure 1 .

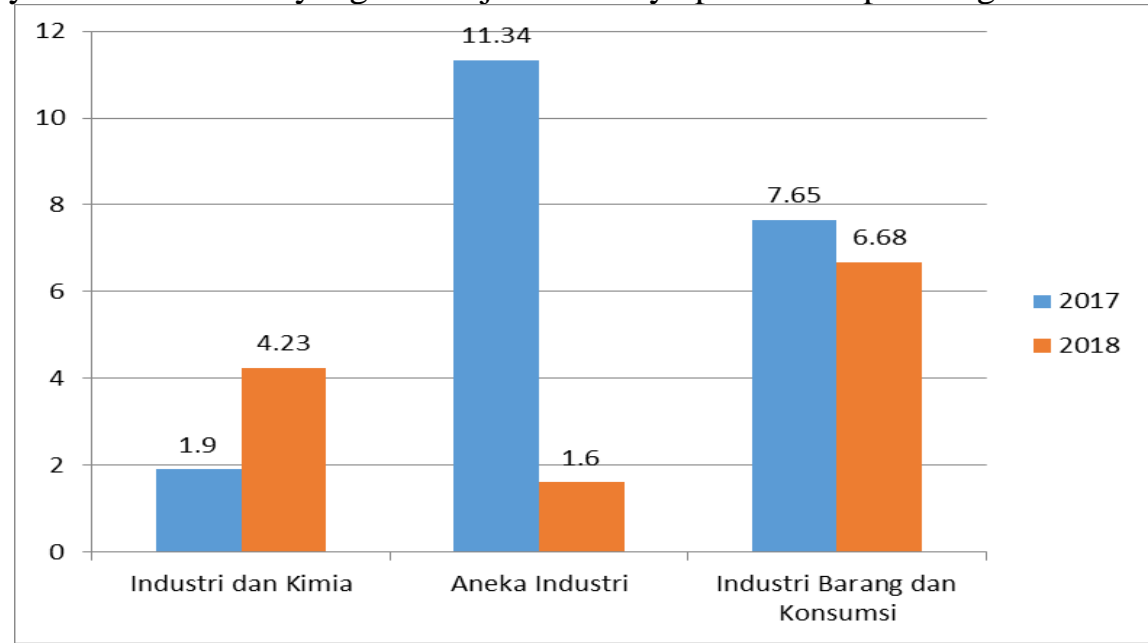

Figure 1. Presentase rata-rata ROA industri Manufaktur pada tahun $2017-2018$

Sumber : www.idx.com, 2019

Perlambatan pertumbuhan terbesar terjadi pada kelompok aneka industri yang hanya mencapai pertumbuhan sebesar $1,6 \%$ pada tahun 2018 dari pertumbuhan sebesar 11,32\% pada tahun 2017. selanjutnya pertumbuhan industri dan kimia berkembang dari 1,9\% pada tahun 2017 menjadi sebesar 4,23\% pada tahun 2018. Sementara itu pertumbuhan industri barang dan konsumsi melambat dari sebesar 7,65\% pada tahun 2017 menjadi sebesar 6,68\% pada tahun 2018. Ketiga sektor ini memegang peranan penting penting dalam kontribusinya pada pertumbuhan industri.

Adapun kelompok industri yang mengalami pertumbuhan adalah industri dan kimia. Pada tahun 2018 yang mencapai sebesar 2,33\% hal ini menyebabkan kontribusi industri dan kimia terus meningkat karena volume ekspor industri dan kimia mengalami peningkatan yang cukup tinggi dibandingkan pada tahun 2017. Sebaliknya pertumbuhan industri dan kimia yang sebesar 4,23\% pada tahun 2018 yang jauh lebih tinggi dari pertumbuhan industri dan kimia yang sebesar 1,9\% pada tahun 2017. Sedangkan perusahaan dalam kelompok aneka industri yang mengalami kontaksi pertumbuhan mengalami penurunan produksi, sehingga untuk seluruh tahun 2018 mencatatkan kontaksi sebesar 1,6\%. Meskipun melambat, namun pertumbuhan aneka industri pada tahun 2018 cukup tinggi terutama jika dibandingkan dengan tahun 2016.

Rendahnya pertumbuhan industri barang dan konsumsi pada tahun 2018 disebabkan karena melambatnya pertumbuhan industri barang dan konsumsi pada tahun tersebut dikarenakan turunnya harga minyak kelapa sawit dunia yang berdampak pada penurunan nilai ekspor kelapa sawit dan nilai ekspor industri. Lebih tingginya pertumbuhan barang dan konsumsi pada tahun 2017, disebabkan karena meningkat pesatnya pertumbuhan industri makanan pada tahun 2017 terkait erat dengan peningkatan ekspor kelompok industri ini yang pada tahun 2017 naik sebesar $7,65 \%$.

Faktor-faktor lainnya yang mempengaruhi financial distress dalam memprediksi kebangkrutan antara lain likuiditas, profitabilitas, operating capacity, leverage dan firm growth. [9]. Likuiditas merupakan kapasitas perusahaan untuk melunasi kewajibannya dengan menggunakan aset lancar [9]. Likuiditas dipakai untuk menghitung kapasitas industri dan membayar utang yang telah jatuh tempo. Current ratio digunakan untuk menunjukan kapasitas

JURNAL ILMIAH KOMPUTERISASI AKUNTANSI Vol. 13 No.1, 2020 : 143-151 
industri dalam melengkapi kewajiban jangka pendeknya memakai aktiva lancarnya. Hasil penelitian menunjukkan bahwa likuiditas berpengaruh signifikan dan negatif terhadap financial distress [17]. Sementara itu, penelitian yang lain menyebutkan bahwa lidkuiditas tidak berpengaruh terhadap financial distress. [9].

Leverage yaitu rasio yang menunjukan kapasitas industri untuk memenuhi total kewajibannya [9]. Leverage merupakan rasio hutang pada ekuitas yaitu rasio yang dipakai untuk menghitung kualitas pemanfaatan hutang pada total ekuitas pemegang saham yang dimiliki oleh industri. Rasio hutang terhadap ekuitas menunjukan presentase penyediaan dana oleh pemegang saham kepada penyumbang kredit. Leverage merupakan alat yang digunakan untuk menunjukan semakin tinggi aktivitas industri yang dianggarai oleh utang, maka akan semakin tinggi pula kesempatan akan terjadinya financial distress [18] . Dari penelitian lainnya menunjukkan bahwa leverage berpengaruh positif dan signifikan terhadap financial distress [17]. Namun berbeda dengan penelitian lainnya menunjukkan bahwa leverage tidak berpengaruh terhadap financial distress [4].

Operating Capacity (TOTA) adalah rasio yang mengukur kapasitas industri mengatur modalnya untuk oprasi. Pada rasio ini menunjukan beberapa baik pengurus aset oleh industri dalam menciptakan output untuk menciptakan keuntungan sehingga bebas dari masalah finansial. Industri mampu menghasilkan jumlah penjualan yang tinggi ditunjukkan dengan Operating capacity yang tinggi, sehingga jumlah pejualan perusahaan akan ditingkatkan dan sebaliknya [17] . Hasil penelitian lainnya menemukan bahwa profitabilitas berpengaruh negatif dan signifikan terhadap financial distress. [2]

Profitabilitas yaitu rasio yang digunakan untuk mengukur kapasitas industri untuk memperoleh keuntungan yang dihasilkan [9]. Profitabilitas merupakan kapasitas industri untuk menciptakan laba. ROA adalah rasio yang merupakan perputaran modal industri yang diukur dari kuantitas industri. ROA menunjukkan kemampuan dan efektivitas penggunaan kekayaan industri karena rasio ini menghitung kapasitas industri dalam menciptakan keuntungan pada pemakai modalnya. Hal tersebut diperkuat dari hasil penelitian yang menyatakan bahwa profitabilitas berpengaruh negatif dan signifikan terhadap financial distress [1] ; [19], berbanding terbalik dengan dengan peneltian lainnya yang menunjukkan profitabilitas tidak berpengaruh signifikan terhadap financial distress. [15].

Firm Growth yaitu kemampuan perusahaan untuk memajukan ukuran perusahannya. Rasio ini rasio yang menggambarkan penyelenggara industri dalam melaksanakan aktifitas operasinya dari tahun ke tahun [11]. Hasil penelitian lainnya menunjukkan bahwa firm growth berpengaruh negatif dan signifikan terhadap financial distress[20], berbanding terbalik dengan penelitian lainnya yang menunjukkan bahwa firm growth tidak berpengaruh terhadap financial distress. [11].

\section{Research Method}

Pada penelitian ini menggunakan uji statsitik deskriptif dan uji hipotesis dengan menggunakan regresi linear berganda. Model regresi yang digunakan pada penelitian ini adalah sebagai berikut:

$\mathrm{FD}=\alpha+\beta 1 \mathrm{LIK}+\beta 2 \mathrm{LEV}+\beta 3 \mathrm{OPRCAP}+\beta 4 \mathrm{PROF}+\beta 5 \mathrm{FMGR}+e$

Dalam penelitian ini yang digunakan sebagai variable independen yaitu likuiditas (LIK), leverage (LEV), Operating Capacity (OPRCAP), Profitabilitas (PROF) dan Firm Growth (FMGR) dan variabel dependen financial distress (FD). Financial distress dapat diukur dengan menggunakan rumus sebagai berikut : [15] 


$$
I C R=\frac{E B I T}{\text { Interest expense }}
$$

Likuiditas merupakan keterkaitan perusahaan dengan kemampuan untuk menyanggupi finansialnya yang harus dipenuhi. potensi untuk mengatasi dan membayar kewajiban perusahaan belum bisa memenuhi kebutuhan financial dari perusahaan. Rasio likuiditas bisa diukur menggunakan Current rasio yaitu membandingkan aktiva lancar dengan hutang [21] :

$$
\text { Current Asset }
$$

$$
\text { Current Ratio }=\frac{\text { Current Liabilities }}{\text { Cung }}
$$

Leverage merupakan rasio yang menunjukan potensi industri mencukupi total hutang [21]. Karena itu perusahaan menghindari pembiayaan dengan menggunakan utang. Ini adalah resiko bagi perusahaan di masa depan karena hutang lebih banyak dari aset. Jika situasi tidak diselasaikan dengan benar potensi kesulitan keuangan akan lebih besar [7]. Dalam penelitian ini menggunakan Debt ratio bisa dirumuskan sebagai berikut [7]:

$$
\text { Leverage }=\frac{\text { Total Debt }}{\text { Total Asset }}
$$

Operating Capacity yaitu menghitung semua kali jumlah modal industri menciptakan perdagangan. Operating Capacity menghitung seluruh modal kepemilikan industri dan menghitung berapa jumlah penjualan yang didapatkan dari setiap rupiah aktiva. Operating Capacity diukur menggunakan total asset turnover atau (TOTA) [24]:

$$
\text { TOTA }=\frac{\text { Sales }}{\text { Total sales }}
$$

Profitabilitas yaitu kapasitas industri untuk memperoleh laba yang dihasilkan Manajemen harus dapat mengelola aset secara efektif sesuai dengan porsi yang dibutuhkan untuk operasional kegiatan sehingga perusahaan mendapat untung lebih tinggi. Semakin besar pada rasio profitabilitas maka semakin efisien industri selama menciptakan laba memakai memanfaatkan asetnya, sehingga kemungkinan kesulitan keuangan menjadi lebih kecil [13]. Profitabilitas perusahaan sebagai predictor financial distress diukur dengan : [13]

$$
\text { Return on Assets }(\text { ROA })=\frac{\text { Earning After Taxes }}{\text { Total Assets }}
$$

Firm Growth merupakan rasio yang berfungsi sebagai alat untuk memperkirakan besar kecilnya suatu perusahaan untuk menjaga kondisi finansalnya apakah sudah searah pada tindakan usahanya yang terus berkembang [17]. Firm Growth dirumuskan sebagai berikut : [8]

$$
\text { Sales Growth }=\frac{\text { sales }^{t}-\text { sales }^{t-1}}{\text { sales }^{t-1}}
$$

Populasi dari penelitian ini dilakukan di industri manufaktur yang terdaftar di Bursa Efek Indonesia (BEI) yang menyertakan rasio keuangannya pada periode 1 januari 2017 sampai 31 Desember 2018 sebanyak 112 perusahaan. Metode dari pemilihan sampel pada penelitian ini yaitu dengan memakai metode purposive sampling. Kualifikasi dalam pengambilan sampel dalam penelitian ini yaitu industri manufaktur yang menerbitkan laporan keuangan dan mempunyai laba positif secara tetap pada periode 2017-2018. Sampel penelitian ini sejumlah 65 perusahaan yang menerbitkan laporan lengkap dan mempunyai laba positif pada periode 2017-2018, sehingga data yang dapat diolah sebanyak 130 data. 
3. Results and Analysis

3.1. Hasil Uji Deskriptif

Tabel 1. Deskriptif Statistik

\begin{tabular}{lcrrrr}
\hline & $\mathrm{N}$ & \multicolumn{1}{c}{ Min } & \multicolumn{1}{c}{ Max } & \multicolumn{1}{c}{ Mean } & \multicolumn{1}{c}{ Std.Dev } \\
\hline Financial Distress & 130 & -120.00 & 333.47 & 57.9313 & 68.96959 \\
\hline Likuiditas & 130 & 12.47 & 728.18 & 221.7606 & 134.11132 \\
\hline Leverage & 130 & -1.26 & 3.82 & 1.0293 & .81720 \\
\hline Operating Capacity & 130 & -20.30 & 157.90 & 77.3202 & 38.07212 \\
\hline Profitabilitas & 130 & -9.71 & 19.73 & 2.9823 & 4.59193 \\
\hline Firm Growth & 130 & -54.70 & 43.02 & -4.7055 & 17.89900 \\
\hline $\begin{array}{l}\text { Valid N } \\
\text { (listwise) }\end{array}$ & 130 & & & & \\
\hline
\end{tabular}

Berdasarkan tabel 1 di atas dapat dijelaskan bahwa variabel financial distress memiliki standard devisiasi sebesar 68.96959 dengan nilai minimum -120.00 dan nilai maksimum 333.47. Variabel likuiditas memiliki standard devisiasi sebesar 134.11132 dengan nilai minimum 12.47 dan nilai maksimum 3.82. Variabel leverage memiliki standard devisiasi sebesar 0.81720 dengan nilai minimum $-1,26$ dan nilai maksimum 3.82. Variabel operating capacity memiliki standard devisiasi sebesar 77.3202 dengan nilai minimum -20.30 dan nilai maksimum 157.90. Variabel profitabilitas memiliki standard devisiasi sebesar 2.9823 dengan nilai minimum -9.71 dan nilai maksimum 19.73.Variabel firm growth memiliki standard devisiasi sebesar -4.7055 dengan nilai minimum -54.70 dan nilai maksimum 43,02.

\subsection{Hasil Analisis Regresi}

Tabel 2. Hasil Analisis Regresi

\begin{tabular}{|c|c|c|c|c|c|}
\hline \multirow[t]{2}{*}{ Model } & \multicolumn{2}{|c|}{$\begin{array}{l}\text { Unstandardized } \\
\text { Coefficients }\end{array}$} & \multirow{2}{*}{$\begin{array}{c}\text { Standardiz } \\
\text { ed } \\
\text { Coefficient } \\
\text { s }\end{array}$} & \multirow[t]{2}{*}{$\mathrm{T}$} & \multirow[t]{2}{*}{ Sig. } \\
\hline & B & Std. Error & & & \\
\hline (Constant) & 94.482 & 20.416 & & 4.628 & .000 \\
\hline Likuiditas & -.119 & .052 & -.232 & -2.285 & .024 \\
\hline Leverage & -9.090 & 7.493 & -.108 & -1.213 & .227 \\
\hline $\begin{array}{l}\text { Operating } \\
\text { Capacity }\end{array}$ & -.232 & .157 & -.128 & -1.482 & .141 \\
\hline Profitabilitas & 6.296 & 1.496 & .419 & 4.209 & .000 \\
\hline Firm Growth & .339 & .332 & .088 & 1.020 & .310 \\
\hline
\end{tabular}

a. Dependent Variable: Financial Distress

Berdasarkan hasil pengujian regresi pada tabel 2 terlihat bahwa likuiditas berpengaruh negatif dan signifikan terhadap financial distress. Hasil penelitian menunjukan t sebesar -2.285 dengan p- value sebesar 0.024. Karena p-value yang dihasilkan lebih kecil dari $0.05(\alpha=5 \%)$. Dalam penelitian ini, likuiditas mempunyai pengaruh siginifikan dan negatif terhadap financial distress mengidentifikasi bahwa aset lancar yang besar bisa menutupi utang lancar suatu perusahaan terbilang sedikit, maka perusahaan mengakibatkan kesulitan untuk jangka pendeknya sebelum jatuh tempo. Hasil ini sesuai dengan penelitian yang dilakukan oleh Damayanti (2017) dan Rahmayanti (2018) yang berhasil membuktikan likuiditas berpengaruh signifikan dan negatif

Rasio Keuangan, Financial Distress Dalam Prediksi Kebangkrutan Perusahaan Manufaktur.. (Firda Rismadhani, Ana Kadarningsih) 
terhadap financial distress. Tingkat rasio likuiditas yang semakin tinggi akan berpengaruh perusahaan yang semakin sehat dan mampu melengkapi kewajiban jangka pendeknya melalui aset lancar secara keseluruhan.

Pada tabel 2 juga terlihat bahwa leverage tidak berpengaruh terhadap financial distress. Hasil statistik pengaruh leverage terhadap financial distress adalah t sebesar -1.213 dengan pvalue sebesar 0.227. Karena p-value yang dihasilkan lebih besar dari $0.05(\alpha=5 \%)$. Hasil penelitian tersebut mengartikan bahwa perubahan DER tidak mempengaruhi perubahan financial distress atau dengan kata lain jika nilai DER naik maka tidak selalu diikuti dengan kenaikan financial distress dan sebaliknya. Besar kecilnya nilai DER tidak mempengaruhi kondisi financial distress dapat disebabkan oleh perusahaan yang memiliki resiko tidak bisa melunasi atau debt ratio kecil tidak menjamin terlepas dari kondisi kesulitan keuangan. Hal ini disebabkan perusahaan tidak menggunakan assetnya yang dibiayai dengan utang secara optimal dan tepat sasaran, yang akhirnya menyebabkan perusahaan mengalami kerugian dan perubahan nilai modal sendiri dari saham perusahaan yang bukan merupakan hasil kerja para agen. Perusahaan dengan DER yang besar belum tentu dibilang menjadi perusahaan yang mendapati financial distress, dan sebaliknya perusahaan dengan jumlah DER yang kecil belum tentu dibilang menjadi perusahaan non financial distress. Hasil penelitian ini mendukung penelitian yang berhasil membuktikan leverage tidak memiliki pengaruh terhadap financial distress. [4].

Operating capacity tidak bepengaruh terhadap financial distress. Hasil penelitian menunjukan t sebesar -1.482 dengan p-value sebesar 0.141. Karena p-value yang dihasilkan lebih besar dari $0.05(\alpha=5 \%)$, dari $0.05(\alpha=5 \%)$. Operating capacity yang dirumuskan dengan total asset turn over (TOTA) merupakan rasio yang digunakan guna mengukur keefektivitasan mengelola aset pada suatu perusahaan. Dalam hal ini perusahaan, perusahaan belum mengelola aset dengan baik untuk meningkatkan produksi perusahaan, karena produksi yang meningkat dari kemampuan perusahaan dalam mengelola aset diharapkan akan menaikkan penjualan. Dengan meningkatnya penjualan, maka berdampak pada laba yang akan diperoleh oleh perusahaaan. Oleh karena itu, operating capacity dapat dikatakan tidak berpengaruh pada financial distress. [14]. Namun berbeda dengan penelitian lainnya yang menemukan bahwa operating capacity berpengaruh terhadap financial distress. [6]; [5].

Profitabiltas berpengaruh positif dan signifikan terhadap financial distress. Hasil penelitian menunjukan t sebesar 4.209 dengan p- value sebesar 0.000. Karena p-value yang dihasilkan lebih kecil dari $0.05(\alpha=5 \%)$, dari $0.05(\alpha=5 \%)$, hal ini menunjukan profitabilitas bepngaruh positif dan signifikan terhadap financial distress. Hal ini menunjukan efisiensi dan evektifitas dari penggunaan asset karena rasio ini mengukur kapasitas industri menciptakan keuntungan bersumber pemakaian modal. Dengan adanya efetivitas dari pemakaian modal industri maka dapat menurunkan dana yang dikeluarkan oleh industri, dengan begitu industri mendapat penghematan dan akan memiliki kecukupan dana untuk menjalankan usahanya. Dengan adanya kecukupan dana tersebut, maka kemungkinan industri mendapati kesulitan keuangan akan menjadi lebih rendah. Variable ini tidak berpengaruh karena ketika ketika industri menurun namun kewajiban biaya-biaya lain masih dapat industri mencukupi dengan memakai biaya dalam atau luar idustri maka variabel ini kurang menjadi tolok ukur dalam prediksi financial distress. Profit margin dalam penelitian ini tidak mempengaruhi keadaan financial distress karena terdapat banyak dampak yang menyebabkan terjadinya perubahan keuntungan bersih terhadap penjualan dari tahun ke tahun, sehingga investor cenderung mengabaikan informasi profit margin yang ada secara maksimal sehingga manajemen pun tidak termotivasi dalam mengetahui kondisi financial distress melalui variabel tersebut karena koefisien manajemen juga turut berperan penting dalam proses pengukuran kemampuan perusahaan dalan kondisi financial distress. Profit margin bukanlah merupakan tolok ukur dalam mengukur kondisi financial distress perusahaan [16]. Hasil Penelitian ini sesuai dengan penelitian yang menemukan bahwa profitabilitas berpengaruh signifikan terhadap financial distress [1]; [23] .

JURNAL ILMIAH KOMPUTERISASI AKUNTANSI Vol. 13 No.1, 2020 : $143-151$ 
Firm growth tidak berpengaruh terhadap financial distress. Hasil penelitian menunjukan $\mathrm{t}$ sebesar 1.020 dengan p-value sebesar 0.310. Karena p-value yang dihasilkan lebih besar dari 0.05 $(\alpha=5 \%)$, dari $0.05(\alpha=5 \%)$. Hasil ini menggambarkan bahwa firm growth tidak berpengaruh signifikan terhadap financial distress dikarenakan pertumbuhan yang tinggi belum tentu memiliki beban yang sedikit, sehingga laba yang dihasilkan hanya sedikit dan kemungkinan financial distress akan semakin besar pada sebuah perusahaan dengan kata lain variabel firm growth tidak mempuyai pengaruh yang signifikan dalam menentukan perubahan variabel financial distress secara parsial. Artinya bahwa variabel firm growth tidak menjadi predictor yang tepat dalam mengukur financial distress perusahaan dalam mempertahankan kondisi perekonomiannya ditengah pertumbuhan perekonomian dan sektor usahanya. Rasio ini tidak begitu menjadi acuan utama saat mengukur financial distress karena penurunan penjualan tidak secara langsung membuat perusahaan mengalami kabengkrutan, hanya mengurangi laba dan selama penurunan penjualan tidak melampaui batas maka tidak begitu bermasalah. Hasil ini mendukung penelitian yang mengatakan firm growth tidak terdapat pengaruh terhadap financial distress. [12]. Sebaliknya, berbeda dengan penelitian yang lainnya yang menemukan bahwa firm growth bepengaruh terhadap financial distress. [10].

\subsection{Uji Koefisien Determinasi}

Tabel 3. Hasil Uji Koefisien Determinasi

\begin{tabular}{lc|r|r|r|r}
\multicolumn{7}{c}{ Model Summary } \\
\hline Model & $\mathrm{R}$ & R Square & $\begin{array}{c}\text { Adjusted R } \\
\text { Square }\end{array}$ & $\begin{array}{c}\text { Std. Error of the } \\
\text { Estimate }\end{array}$ & $\begin{array}{l}\text { Durbin- } \\
\text { Watson }\end{array}$ \\
\hline 1 & $.607^{\mathrm{a}}$ & .369 & .316 & .98552 & 1.842 \\
\hline
\end{tabular}

a. Predictors: (Constant), Firm Growth, Leverage, Operating Capacity,

Profitabilitas, Likuiditas

b. Dependent Variable: Financial Distress

Pada penelitian ini, analisis koefisien determinasi diuji untuk mengetahui seberapa besar keterkaitan antara variabel bebas yaitu : Likuiditas, Leverage, Operating Capacity, Profitabilitas dan Firm Growth terhadap Financial Distress. Pada tabel 3 terlihat bahwa nilai koefisien determinasi (Adjusted $R^{2}$ ) adalah sebesar 0,316. Hal ini berarti bahwa variabel Likuiditas, Leverage, Operating Capacity, Profitabilitas dan Firm Growth mampu menerangkan Financial Distress sebesar 31,6\%. Sedangkan sisanya yaitu sebesar $100 \%-31,6 \%=68,4 \%$ dijelaskan oleh faktor-faktor lain selain variabel bebas yang diteliti.

\section{Conclusion}

Likuiditas dan profitabilitas mempunyai pengaruh yang signifikan terhadap finansial distress yang merupakan prediksi kebangkrutan suatu perusahaan. Likuiditas mempunyai pengaruh negatif dan signifikan terhadap financial distress, sedangkan profitabilitas mempunyai pengaruh positif dan signifikan terhadap financial distress. Tiga variabel independen yang lainnya yaitu pperating capacity, leverage dan firm growth tidak mempunyai pengaruh terhadap financial distress. Pada penelitian ini yang mempunyai pengaruh lebih besar dan signifikan terhadap financial distress pada perusahaan manufaktur adalah profitabilitas. Selanjutnya diikuti variabel likuiditas yang mempunyai pengaruh terbesar kedua terhadap financial distress. .

Keterbatasan dalam penelitian ini antara lain periode pengamatan yang cukup pendek selama dua tahun. Selain itu nilai adjusted R2 juga masih redah yaitu 31,6\% yang mengindikasikan bahwa masih ada variabel-variabel lain yang mempengaruhi financial distress sebanyak $68,4 \%$. Keterbatasan yang lainnya yaitu sampel penelitian yang digunakan hanya 
industri manufaktur yang terdaftar di BEI, sehingga hasilnya tidak bisa di generelasasi untuk jenis perusahaan lainnya.

Penelitian selanjutnya dapat meneliti variabel-variabel independen lain seperti rasio investasi, rasio aktivitas, ukuran perusahaan yang dilihat dari umur perusahaan, maupun dari kinerja pasar perusahaan seperti nilai perusahaan maupun market sales. Sedangkan objek penelitian dapat menggunakan perusahaan selain manufaktur, misalnya perusahaan perbankan yang terdaftar di OJK, perusahaan asuransi yang terdaftar di OJK atau perusahaan milik pemerintah (BUMN).

\section{References}

[1] Alifiah. (2014). Prediction Of Financial Distress Companies In The Trading And Services Sector In Malaysia Using Macroesonomic Variable. Procedia-Sosial and Behavioral Sciences. 2014:12(9). 90-98.

[2] Agung Dharmawan. The Effect Of Liquidity, Profitability And Solvability To The Financial Distress Of Manufactured Companies Listed On The Indonesia Stock Exchange (IDX) Period Of Year 2015-2017. Academy of accounting and financial studies journal. 2019:

[3] Alvina. (2019). Analisis Rasio Keuangan Untuk Memprediksi Kondidi Financial Distress Perusahaan Manifaktur Yang Terdaftar Di BEI. JAAI. 2019: 2(2). 183-210

[4] Deviacita, A. W. Achmad, T. Analisis Pengaruh Mekanisme Corporate Governance terhadap kondisi Financial Distress. Diponegoro Journal of Accounting. 2012: 2(2), 1-15.

[5] Elen .Pengaruh Rasio Likuiditas, Leverage, Operating Capacity, Dan Sales Growth Terhadap Financial Distress. E-Journal Akuntansi Universitas Udayana. 2019: 11(2). 456469.

[6] Erni. The Influence of Liquidity, Leverage, and Profitability on Financial Distress of Listed Manufacturing Companies in Indonesia. Advances in Economics, Business and management research. 2018: Vol.57

[7] Hanifah. Pengaruh Struktur Corporate Governance Dan Financial Indicator Terhadap Kondisi Financial Distress. Diponegoro Journal of accounting. 2013: 2(2),1-15.

[8] Harahap. Analisis Kritis atas Laporan Keuangan. Jakarta: Raja Grafindo Persada. 2011.

[9] Hidayat. Meiranto. Prediksi Financial Distress Perusahaan Manufaktur Di Indonesia. Diponegoro Jurnal Akuntansi. 2014: 3(2), 1-11.

[10] Jamal. Shah. The Impact Of Corporate Governance On The Cost Of Equity : Emperical Evidence From Pakistan Listed Companies. Jinnah Business Review. 2017: 5(2). 49-53.

[11] Julius. Pengaruh Financial Leverage, Firm Growth, Laba dan Arus Kas terhadap Financial Distress (Studi Emperis pada Perusahaan Manufaktur yang terdaftar di Bursa Efek Indonesia Tahun 2010-2014). JOM Fekon. 2017:

[12] Joicenda. Agustina . (2019). Investigating The Effect Of Liquidity, Leverage, Sales Growth And Good Corporate Governance On Financial Distress. Journal Of Accounting And Strategic Finance. 2019: 2(2). 143-156.

[13] Kristiani. Nuhumury. The Effect Of Public Accounting Firm Size, Financial Distress, Institutional Ownship, And Management Change On The Auditor Switching In Manufacturing Companies Listed In Indonesian Stock Exchanges. Journal Economi. 2014: 22(1). 1-6.

[14] Kusanti. Andayani. (2015). Pengaruh Good Corporate Governance Dan Rasio Keuangan Terhadap Financial Distress. Jurnal Ilmu dan Riset Akuntansi. 2015: 4(10). 1-22.

[15] Lilis. The effect of leverage, liquidity and profitability on financial distress with the effectiviness of the audit Commitee as a moderating variable. Accounting Analysis Journal .2019: 8(1). 38-44.

[16] Manzaneque, et al. Corporate Governace Effect On Financial Distress Likelihood : Evidence From Spain . Spanish Accounting Review. 2015:19(1).111-121.

JURNAL ILMIAH KOMPUTERISASI AKUNTANSI Vol. 13 No.1, 2020: 143-151 
[17] Puspita, M. R. (2019). Faktor-Faktor Yang Mempengaruhi Financial Distress Pada Perusahaan Manufaktur Indonesia. Jurnal AKSI ( Akuntansi dan Sistem Informasi). 2019: 4 (1), 1-12.

[18] Rahmayanti. Hadromi. Analisis Financial Distress Pada Perusahaan Manufaktur Yang Terdaftar. Jurnal Akuntansi \& Ekonomika, 2017:Vol 7.

[19] Rusli. Pengaruh Rasio Keuangan terhadap kondisi financial distress perusahaan otomotif. Jurnal Bisnis dan Akuntansi. 2019: 11(2)

[20] Salloum, et al. Audit Commitee And Financial Distress In The Middle East Context : Evidence Of The Lebanese Financial Instutions. Internasional Strategic Manegement Review. 2014: 2(1). 370-380.

[21] Sudana. Manajemen keuangan perusahaan., Jakarta : Erlangga. 2015:Vol.2

[22] Utami, I. W. Pengaruh Operating Capacity, Quick Ratio, Modal Kerja dan Cash flow to sales terhadap Financial distress pada perusahaan properti dan real estate yang terdaftar di BEI periode 2015-2017. 2019:

[23] Verani. Analisis Rasio keuangan untuk memprediksi kondisi Financial Distress (Studi Empiris Perusahaan Manufaktur yang terdaftar di Bursa Efek Indonesia Periode 20142015). Jurnal Akuntansi Maranatha, 2017:137-145.

[24] Yustika. Pengaruh Likuiditas, Leverage, Profitabilitas, Pperating Capacity, dan Biaya Agensi Menejerial terhadap Financial Distress. Jurnal FEKOM, 2015: Vol.2 